\title{
Study on Interaction Effect of Sulphur and Zinc on Different Parameters of Greengram under Rainfed Condition
}

\author{
Opendra Kumar Singh ${ }^{1}$, T. S. Mishra ${ }^{2}$, H. M. Singh ${ }^{3 *}$ and Shubham Dwivedi ${ }^{1}$ \\ ${ }^{1}$ M.G.C.G.V Chitrkoot Satna, M.P, India \\ ${ }^{2}$ KVK West Kameng Dirang Arunachal Pradesh, India \\ ${ }^{3}$ National Horticultural Research and Development Foundation, Patna Bihar, India \\ *Corresponding author
}

\begin{abstract}
A B S T R A C T
\section{Keywords}

Greengram, Variety, Sulphar, Zinc, Fertility and Management

Article Info

Accepted:

20 July 2020

Available Online:

10 August 2020

The experiment was conducted, during the kharif season of 2014-15 on Green gram Variety PDM-139 at the Rajola Farm of the Faculty of Agricultural Sciences, Mahatma Gandhi Chitrakoot Gramodaya Vishwavidyalaya, Chitrakoot - Satna (Madhya Pradesh) located from $24^{\circ} 31^{\prime} \mathrm{N}$ latitude and $81^{\circ} 15^{\prime}$ E latitude. Chitrakoot is situated at an altitude of $306 \mathrm{~m}$ above mean sea level at The climate of the region is semi-arid and sub-tropical having extreme winter and summer. The experiment was Randomized Block Design with three replication. application of $30 \mathrm{~kg} \mathrm{~S}$ with $60 \mathrm{~kg}$ $\mathrm{P} /$ ha proved the most optimum and the beneficial fertility management for the PDM139 Variety Green gram for the Bundelkhand/Chitrakoot region of Madhya Pradesh. This fertility management $\left(\mathrm{S}_{30} \mathrm{Zn}_{10}\right)$ resulted in maximum seed productivity up to $12.63 \mathrm{q} /$ ha and straw yield up to $12.63 \mathrm{q} / \mathrm{ha}$.
\end{abstract}

\section{Introduction}

Greengram is also known as mung, moong, mungo, goldengram, chick a saw pea and oregon pea. Development of short duration as well as photo and thermo insensitive varieties provided excellent opportunity for greengram cultivation both in kharif as well as in summer season, where adequate irrigation facilities are available (Patel et al. 2013). Mungbean, being a rich source of protein, needs to be judiciously fertilized with $S$, as this element plays a key role in protein synthesis. Sulphur is a constituent of essential amino acids - methionine, cysteine and cystine- the building blocks of protein. Sulphur fertilization is considered critical for seed yield and protein synthesis and for improvement in quality of produce in legumes through their enzymatic and metabolic effects (Bhattacharjee et al., 2013). Cobalt, being a constituent of cobalamine enzyme, plays a key role in governing the number and size of the nodules. Moreover, Co application also increases formation of leghemoglobin required for nitrogen fixation, thereby improves the nodules activity (Awomi et al. 2012). 
Sulphur is considered to be some times forgotten secondary nutrient in crop production. However it is very essential for the synthesis of amino acids and activity of proteolytic enzymes. Sulphur fertilization improves both yield and quality of crops if adequate supply in the field is ensured.

$\mathrm{Zn}$ is involved in auxin metabolism like, tryptophane synthesis, tryptamine metabolism, protein synthesis, formation of nucleic acid and helps in utilization of nitrogen as well as phosphorus by plants. $\mathrm{Zn}$ also stimulates resistance for dry and hot weather, bacterial and fungal diseases and ribosomal fraction in the plants. It also promotes nodulation and nitrogen fixation in leguminous crops (Demeterio et al., 1972). In view of the above the attempts have been made through the present investigation to study the effect of sulphur and zinc on growth, yield and quality of mungbean (Vigna radiata L.) (Ram et al., 2013). Zinc is one of the important heavy metals, which is needed as a micronutrient for plants for various metabolic processes. However at excessive levels, zinc has the potential to become toxic to plants. Zinc has been used increasingly in different forms like nutrients, fungicide, pesticide or disinfectant.

In legumes, sulphur being the constituent of some amino acids, promotes the biosynthesis of protein. Likewise, zinc also plays a vital role in the synthesis of protein and nucleic acids and helps in the utilization of nitrogen and phosphorus by plant. These nutrients play a vital role in bio-synthesis of protein and amino acids. Application of $\mathrm{S}$ and $\mathrm{Zn}$, therefore, has shown significant effects on yield, uptake of nutrients and quality of the crop (Tripathi et al., 1997). The interaction of these nutrient elements may affect the critical levels of available $\mathrm{Zn}$ and $\mathrm{S}$ below which response to their application could be observed (Upadhyay, 2013).

\section{Materials and Methods}

The experiment was conducted, during the kharif season of 2014-15 on Green gram Variety PDM-139 at the Rajola Farm of the Faculty of Agricultural Sciences, Mahatma Gandhi Chitrakoot Gramodaya Vishwavidyalaya, Chitrakoot - Satna (Madhya Pradesh) located from $24^{\circ} 31^{\prime} \mathrm{N}$ latitude and $81^{\circ} 15^{\prime}$ E latitude. Chitrakoot is situated at an altitude of $306 \mathrm{~m}$ above mean sea level at The climate of the region is semiarid and sub-tropical having extreme winter and summer. During the winter months, the temperature drops down to as low as $2^{\circ} \mathrm{C}$ while in the summer the temperature reaches above $47^{\circ} \mathrm{C}$. hot desiccating winds (Loo) are regular feature during summers whereas there may be occasional spell of frost during the winters.. The experiment was laid out in a Randomized Block design with three replication. There were twelve treatment including a control. Treatment combination used of Sulpher and Zinc @ $10 \mathrm{~kg} / \mathrm{ha}$, $20 \mathrm{~kg} / \mathrm{ha}$ and Sulpher 30kg/ha. Growth parameters were taken Plant height, Number of branches, Number of leaves per plant, number of capsules per plant number of seeds per capsules and Yield.

\section{Results and Discussion}

\section{Growth Parameters}

The plant height increased steadily with the increase of plant growth up to 60 days of observation. The plant height at 20 days stage ranged from 8.64 to $12.25 \mathrm{~cm}$ in different treatments, where at 60 days stage, it increased from 44.52 to $50.92 \mathrm{~cm}$. The applied sulphur and Zinc levels exerted significant influence upon this parameter at each stage of observation except at 60 days in case of $\mathrm{S}$ levels. The treatment interactions were found to be significant at every stage. At 20 and 60 days stages, applied Zinc up to $10 \mathrm{~kg} / \mathrm{ha}$ raised 
the plant height significantly over zero level. Thus the maximum height was up to 9.04 and $50.61 \mathrm{~cm}$, respectively rather increase in $\mathrm{Zn}$ level up to $15 \mathrm{~kg} / \mathrm{ha}$ decreased the plant height significantly. Thus, $0 \mathrm{~kg} \mathrm{Zn} / \mathrm{ha}$ were found statistically at par in their influence.

The increasing levels of sulphur only up to 30 $\mathrm{kg} / \mathrm{ha}$ increased the plant height significantly at every stage of observation. Thus the maximum height at 20,40 and 60 days was $12.25,31.20$ and $50.92 \mathrm{~cm}$, respectively. Further increase in $\mathrm{S}$ level up to $30 \mathrm{~kg} / \mathrm{ha}$ tended to increase the plant height almost significantly.

The results in Table 1 reveal that the best treatment interaction was $30 \mathrm{~kg}$. Splus $10 \mathrm{~kg}$ $\mathrm{Zn} / \mathrm{ha}$ which recorded the maximum height i.e. $13.66 \mathrm{~cm}$ at 20 days, $34.30 \mathrm{~cm}$ at 40 days and $52.66 \mathrm{~cm}$ at 60 days stage. This treatment interaction was found significantly superior to most of the remaining having $S$ level only up to $30 \mathrm{~kg} / \mathrm{ha}$ with all the $\mathrm{Zn}$ level. How ever, the second best interaction was $30 \mathrm{~kg} \mathrm{~S}$ plus $15 \mathrm{~kg} \mathrm{Zn} / \mathrm{ha}$. In contrast to this, the significant lowest plant height was recorded in case of without $\mathrm{S}$ and $\mathrm{Zn}$ application (absolute control).

The number of secondary and tertiary branches/plant was recorded in each treatment and the mean values are presented in Table 2. The different sulphur and Zinc levels brought about significant changes in the number of branches per plant. The sulphur and Zinc interaction was also found significant in both the types of branches.

Application of Zinc only up to $10 \mathrm{~kg} / \mathrm{ha}$ resulted in significant increase in the secondary branches (5.14/plant) as well as tertiary branches (6.25/plant) over no Zinc. The corresponding values at zero level were 3.54 secondary and 6.25 tertiary branches/ plant.
The treatment interaction as were found to be significant (Table 2) accordingly, $30 \mathrm{~kg} \mathrm{~S}$ plus $10 \mathrm{Zn} \mathrm{kg/ha}$ brought about significantly higher secondary and tertiary branches/ plant over most of the remaining interactions. However, the second best interaction was $30 \mathrm{~kg} \mathrm{~S}$ plus $10 \mathrm{~kg} \mathrm{Zn/ha} \mathrm{which} \mathrm{recorded} 6.53$ secondary and 7.80 tertiary branches/plant. Both the interactions $\left(\mathrm{S}_{30} \mathrm{Zn1}_{0}\right)$ were found to differ significantly only in case of secondary branches. The significantly lowest branches (2.80 secondary and 3.73 tertiary) were noted in case of absolute control $\left(\mathrm{S}_{0} \mathrm{Zn}_{0}\right)$.

The number of trifoliate leaf green gram at 20, 40, and 60 days growth intervals. The mean values are presented in Table 3 . The different sulphur and Zinc levels brought about significant changes in the number of trifoliate leaf/ plant. The sulphur and Zinc interaction was also found significant in both the types of trifoliate leaf. Application of sulphur only up to $30 \mathrm{~kg} / \mathrm{ha}$ resulted in significant increase in the trifoliate leaf (33.41/plant) as well as no sulphur (29.13) at the 60 days. The increasing Zinc levels only up to $10 \mathrm{~kg} / \mathrm{ha}$ increased these parameters significantly (29.14 to $33.05 /$ plant) at the 60days. Farther increased in $\mathrm{Zn}$ levels up to $15 \mathrm{~kg} / \mathrm{ha}$ resulted increased in this parameter significantly. This was noted at every stage of observation. The best treatment interaction was $30 \mathrm{~kg} \mathrm{~S}$ plus $10 \mathrm{Zn} \mathrm{kg/ha} \mathrm{which} \mathrm{recorded}$ the maximum trifoliate leaf i.e. 13.76 at 20 days, 23.73 at 40 days and 36.76 at 60 days stage. This treatment interaction was found significantly superior to the remaining having $\mathrm{S}$ level only up to $30 \mathrm{~kg} / \mathrm{ha}$ with all the $\mathrm{Zn}$ level. In contrast to this, the significant trifoliate leaf was recorded in case of without $\mathrm{S}$ and $\mathrm{Zn}$ application (absolute control).

The increasing levels of sulphur up to $30 \mathrm{~kg} / \mathrm{ha}$ increased the root length significantly at each stage of observation. Accordingly the maximum root length at 20,40 and 60 days 
stage was 5.62, 7.34 and $10.25 \mathrm{~cm}$ respectively. Further increase in $\mathrm{S}$ levels up to $30 \mathrm{~kg} / \mathrm{ha}$ resulted increase in this parameter significantly. This was noted at every stage of observation. The applied $\mathrm{Zn}$ levels brought about significant influence up on this parameter only at 20 days stage, where as Slevels exerted significant impact at every stage of observation. The treatment interactions were found to be significant at every stage. At 40 days stage, applied Zinc up to $10 \mathrm{~kg} / \mathrm{ha}$ encouraged the root length significantly $(7.00 \mathrm{~cm})$ there was significant difference between $15 \mathrm{~kg} \mathrm{Zn} / \mathrm{ha}$. At 20 and 60 days stage the root length were found statistically identical.

The best treatment combination was $30 \mathrm{~kg} \mathrm{~S}$ plus $10 \mathrm{~kg} \mathrm{Zn} / \mathrm{ha}$ which recorded the maximum root length i.e. $6.33,8.50$ and $11.63 \mathrm{~cm}$ at 20,40 and 60 days stage, respectively (Table 4). This was followed by $30 \mathrm{~kg} \mathrm{~S}$ plus $10 \mathrm{~kg} \mathrm{Zn/ha} \mathrm{interaction.} \mathrm{Both}$ these interactions were found be significantly superior to most of the remaining interactions. On the other hand the significant lowest root length was noted in case of absolute control $\left(\mathrm{S}_{0} \mathrm{Zn}_{0}\right)$.

\section{Yield-attributing parameters}

The number of pod/plant were counted from the randomly sample plants in each plot and the mean data. Sulphur and Zinc levels as well as their interactions were found to exact significant impact upon the formation of pod/plant. Accordingly, the numbers of pod/plant were enhanced significantly up to 21.90 pod due to $30 \mathrm{~kg}$ S/ha over no sulphur (19.02 pod). Further increase in $S$ level up to $30 \mathrm{~kg} / \mathrm{ha}$ bring about any significant change (21.90pod/plant).

As regards with the Zinc levels, the pod were increased significantly with each increased in the $\mathrm{Zn}$ levels only up to $10 \mathrm{~kg} / \mathrm{ha} 22.16$ pod/plant. Thus the maximum $22.16 \mathrm{pod} /$ plant were counted in case of $10 \mathrm{~kg} \mathrm{Zn} / \mathrm{ha}$ as against 18.15 pod /plant in case of no Zinc. The interactions exerted significant changes in this yield-attributing parameter. The best treatment interaction was $30 \mathrm{~kg} \mathrm{~S}$ plus $10 \mathrm{~kg}$ $\mathrm{Zn} /$ ha which recorded significantly higher number of pod (23.80 pod/plant) over all the remaining $\mathrm{S} x \mathrm{Zn}$ interactions except $\mathrm{S}_{30} \mathrm{Zn}_{10}$ and $\mathrm{S}_{20} \mathrm{Zn}_{10}$ (23.80 to $22.60 \mathrm{pod} / \mathrm{plant}$ ). In contrast to this, the significantly lowest pod (16.80pod/plant) was counted in case of absolute control $\left(\mathrm{S}_{0} \mathrm{Zn}_{0}\right)$.

The different treatments as well as treatment interactions were found it deviate this parameter significantly. Accordingly, $30 \mathrm{~kg}$ S/ha produced maximum 11.26 seeds/pod and seeds/pod proved significantly superior to no sulphur (8.23 seed/pod). The increasing levels of Zinc only up to $10 \mathrm{~kg} / \mathrm{ha}$ enhanced the seed number significantly (11.02 seeds/pod). However further increase in $\mathrm{Zn}$ level this parameter. Higher dose of Zinc proved advantageous (9.95 seeds/pod). The significantly lowest seeds (8.05/pod) were obtained in case of no Zinc. The treatment interactions were found to be significant in accordingly this parameter. Thus the best interaction was $30 \mathrm{~kg}$ S plus $10 \mathrm{~kg} \mathrm{Zn} / \mathrm{ha}$ which recorded significantly higher seed count (12.70 plant/pod).In contrast to this the significantly lowest seed count only 6.60 seeds/pod were noted in case of absolute control $\left(\mathrm{S}_{0} \mathrm{Zn}_{0}\right)$.

The test weight of 1000 grains was recorded treatment wise and the The mean values are presented in Table 5. The different levels of Zinc as well as $\mathrm{S} \times \mathrm{Zn}$ interactions were found to exact significant influence upon the test weight. The sulphur levels were found to have identical influence upon this parameter. The test weight ranged from $17.08 \mathrm{~g}$ in case of 30 $\mathrm{kg} \mathrm{S} / \mathrm{ha}$ to $11.81 \mathrm{~g}$ in case of no sulphur. The increasing levels of Zinc up to $10 \mathrm{~kg} / \mathrm{ha}$ 
increased the test weight significantly $(16.98 \mathrm{~g})$. Thus the maximum test weight $16.98 \mathrm{~g}$ was recorded in case of no Zinc applications (11.56 g). Amongst the treatment interactions which were significant, $\mathrm{S}_{30} \mathrm{Zn}_{10}$ resulted in maximum test weight up to 19.46 $\mathrm{g}$, being significantly superior to $\mathrm{S}_{30} \mathrm{Zn} 1_{0}$ interactions $(19.46 \mathrm{~g})$ were found statistically identical in their influence. The lowest test weight $(9.43 \mathrm{~g})$ was recorded in case control $\left(\mathrm{S}_{0} \mathrm{Zn}_{0}\right)$.

\section{Productivity parameters}

The different levels of sulphur and Zinc brought about significant influence upon the grain yield of green gram however the treatment interactions were found to be significant. Applications of sulphur up to $30 \mathrm{~kg} / \mathrm{ha}$ the grain yield significantly up to $10.96 \mathrm{q} / \mathrm{ha}$ the father increase in $\mathrm{S}$ level up to $30 \mathrm{~kg} / \mathrm{ha}$, as compared to no sulphur $(8.23$ q/ha) (Table 6 and 7).

Table.1 Plant height $(\mathrm{cm})$ different growth intervals as influenced by sulphur and zinc levels as well as their interactions

\begin{tabular}{|c|c|c|c|c|}
\hline \multirow{3}{*}{$\begin{array}{l}\text { Level of S } \\
\text { (kg/ha) }\end{array}$} & \multicolumn{3}{|c|}{ Levels of Zn (kg/ha) } & \multirow[t]{3}{*}{ Mean } \\
\hline & 0 & 10 & 15 & \\
\hline & \multicolumn{3}{|l|}{ 20DAS } & \\
\hline $\mathbf{0}$ & 7.90 & 9.36 & 8.66 & 8.64 \\
\hline 10 & 8.60 & 10.76 & 9.53 & 9.63 \\
\hline 20 & 9.03 & 10.66 & 9.53 & 9.74 \\
\hline 30 & 10.63 & 13.66 & 12.46 & 12.25 \\
\hline Mean & 9.04 & 11.11 & 10.05 & \\
\hline \multicolumn{5}{|l|}{ 40DAS } \\
\hline $\mathbf{0}$ & 22.03 & 27.76 & 24.93 & 24.91 \\
\hline 10 & 24.03 & 28.86 & 26.30 & 26.40 \\
\hline 20 & 27.10 & 32.03 & 29.83 & 29.65 \\
\hline 30 & 28.76 & 34.30 & 30.53 & 31.20 \\
\hline Mean & 25.48 & 30.74 & 27.90 & \\
\hline \multicolumn{5}{|l|}{ 60DAS } \\
\hline $\mathbf{0}$ & 37.43 & 48.50 & 47.63 & 44.52 \\
\hline 10 & 45.46 & 49.53 & 48.40 & 47.80 \\
\hline 20 & 47.50 & 51.76 & 49.33 & 49.53 \\
\hline 30 & 48.60 & 52.66 & 51.50 & 50.92 \\
\hline \multirow[t]{2}{*}{ Mean } & 44.75 & 50.61 & 49.21 & \\
\hline & & $\mathrm{S}$ & $\mathrm{Zn}$ & SxZn \\
\hline \multirow{2}{*}{ 20DAS } & $\mathrm{SE}(\mathrm{M}) \pm$ & 0.07 & 0.06 & 0.12 \\
\hline & $\mathrm{CD}(\mathrm{p}=0.05)$ & 0.21 & 0.18 & 0.37 \\
\hline \multirow{2}{*}{ 40DAS } & $\mathrm{SE}(\mathrm{M}) \pm$ & 0.13 & 0.12 & 0.24 \\
\hline & $\mathrm{CD}(\mathrm{p}=0.05)$ & 0.40 & 0.35 & 0.70 \\
\hline \multirow{2}{*}{ 60DAS } & $\mathrm{SE}(\mathrm{M}) \pm$ & 0.10 & 0.09 & 0.18 \\
\hline & $\mathrm{CD}(\mathrm{p}=0.05)$ & 0.31 & 0.27 & 0.54 \\
\hline
\end{tabular}


Table.2 Number of secondary and tertiary branches/plant of Green gram as influenced by sulphur and zinc levels as well as their interactions

\begin{tabular}{|l|c|c|c|c|}
\hline \multirow{2}{*}{ Level of S(kg/ha) } & \multicolumn{2}{|l}{ Levels of Zn (kg/ha) } & \multirow{2}{*}{ Mean } \\
\cline { 2 - 4 } & \multicolumn{2}{|c|}{10} & 15 & \\
\cline { 2 - 4 } & Secondary Branches & 3.26 & 3.26 \\
\hline $\mathbf{1 0}$ & 2.80 & 3.73 & 3.63 & 3.82 \\
\hline $\mathbf{2 0}$ & 3.23 & 4.60 & 4.50 & 4.72 \\
\hline $\mathbf{3 0}$ & 3.96 & 5.70 & 5.40 & 5.36 \\
\hline Mean & 4.16 & 6.53 & 4.20 & \\
\hline Tertiary Branches & 3.54 & 5.14 & & \\
\hline $\mathbf{0}$ & & & 4.03 & 4.18 \\
\hline $\mathbf{1 0}$ & 3.73 & 4.80 & 4.80 & 4.84 \\
\hline $\mathbf{2 0}$ & 3.93 & 5.80 & 5.70 & 5.50 \\
\hline $\mathbf{3 0}$ & 4.20 & 6.60 & 6.20 & 6.41 \\
\hline Mean & 5.23 & 7.80 & 5.18 & \\
\hline & 4.27 & 6.25 & $\mathrm{Zn}$ & SxZn \\
\hline Secondary & & $\mathrm{S}$ & 0.05 & 0.10 \\
\hline Branches & $\mathrm{SE}(\mathrm{M}) \pm$ & 0.05 & 0.14 & 0.29 \\
\hline Tertiary Branches & $\mathrm{CD}(\mathrm{p}=0.05)$ & 0.17 & 0.06 & 0.12 \\
\hline & $\mathrm{SE}(\mathrm{M}) \pm$ & 0.07 & 0.18 & 0.37 \\
\hline
\end{tabular}

Table.3 Trifoliate leaf /plant of green gram as influenced by sulphur and Zinc levels as well as their interactions

\begin{tabular}{|c|c|c|c|c|}
\hline \multirow{3}{*}{$\begin{array}{l}\text { Level of } S \\
(\mathrm{~kg} / \mathrm{ha})\end{array}$} & \multicolumn{3}{|c|}{ Levels of Zn (kg/ha) } & \multirow[t]{3}{*}{ Mean } \\
\hline & 0 & 10 & 15 & \\
\hline & \multicolumn{3}{|l|}{ 20DAS } & \\
\hline $\mathbf{0}$ & 7.76 & 10.70 & 9.60 & 9.35 \\
\hline 10 & 8.73 & 11.66 & 10.70 & 10.36 \\
\hline 20 & 9.40 & 12.76 & 11.56 & 11.24 \\
\hline 30 & 10.70 & 13.76 & 12.50 & 12.32 \\
\hline Mean & 9.15 & 12.22 & 11.09 & \\
\hline \multicolumn{5}{|c|}{ 40DAS } \\
\hline $\mathbf{0}$ & 17.66 & 20.70 & 19.40 & 19.25 \\
\hline 10 & 18.60 & 21.56 & 20.36 & 20.17 \\
\hline 20 & 19.53 & 22.66 & 21.13 & 21.11 \\
\hline 30 & 20.43 & 23.73 & 22.50 & 22.22 \\
\hline Mean & 19.05 & 22.16 & 20.85 & \\
\hline \multicolumn{5}{|c|}{ 60DAS } \\
\hline $\mathbf{0}$ & 27.93 & 30.06 & 29.40 & 29.13 \\
\hline 10 & 28.46 & 32.46 & 31.16 & 30.70 \\
\hline 20 & 29.56 & 33.93 & 31.40 & 31.63 \\
\hline
\end{tabular}




\begin{tabular}{|l|l|l|l|l|}
\hline 30 & 30.60 & 35.76 & 33.86 & 33.41 \\
\hline Mean & 29.14 & 33.05 & 31.45 & \\
\hline \multirow{2}{*}{ 20DAS } & & $\mathrm{S}$ & $\mathrm{Zn}$ & $\mathrm{SxZn}$ \\
\hline \multirow{4}{*}{ 40DAS } & $\mathrm{SE}(\mathrm{M}) \pm$ & 0.05 & 0.05 & 0.10 \\
\cline { 2 - 5 } & $\mathrm{CD}(\mathrm{p}=0.05)$ & 0.17 & 0.15 & NS \\
\hline \multirow{2}{*}{ 60DAS } & $\mathrm{SE}(\mathrm{M}) \pm$ & 0.09 & 0.08 & 0.16 \\
\cline { 2 - 5 }$(\mathrm{p}=0.05)$ & 0.28 & 0.24 & $\mathrm{NS}$ \\
\hline & $\mathrm{SE}(\mathrm{M}) \pm$ & 0.14 & 0.12 & 0.25 \\
\cline { 2 - 5 } & $\mathrm{CD}(\mathrm{p}=0.05)$ & 0.43 & 0.37 & 0.74 \\
\hline
\end{tabular}

Table.4 Root length of green gram at different growth intervals as influenced by sulphur and Zinc levels as well as their interactions

\begin{tabular}{|c|c|c|c|c|}
\hline \multirow[t]{3}{*}{ Level $S(\mathrm{~kg} / \mathrm{ha})$} & \multicolumn{3}{|c|}{ Levels of $\mathrm{Zn}(\mathrm{kg} / \mathrm{ha})$} & \multirow[t]{3}{*}{ Mean } \\
\hline & 0 & 10 & 15 & \\
\hline & \multicolumn{3}{|l|}{ 20DAS } & \\
\hline 0 & 3.33 & 4.70 & 4.50 & 4.17 \\
\hline 10 & 4.26 & 5.33 & 4.83 & 4.81 \\
\hline 20 & 4.63 & 5.86 & 5.23 & 5.24 \\
\hline 30 & 4.93 & 6.33 & 5.60 & 5.62 \\
\hline Mean & 4.29 & 5.55 & 5.04 & \\
\hline \multicolumn{5}{|l|}{ 40DAS } \\
\hline 0 & 4.56 & 6.33 & 5.33 & 5.41 \\
\hline 10 & 5.23 & 6.46 & 5.86 & 5.85 \\
\hline 20 & 5.46 & 6.73 & 6.43 & 6.21 \\
\hline 30 & 6.20 & 8.50 & 7.33 & 7.34 \\
\hline Mean & 5.36 & 7.00 & 6.24 & \\
\hline \multicolumn{5}{|l|}{ 60DAS } \\
\hline 0 & 6.46 & 8.36 & 7.53 & 7.45 \\
\hline 10 & 7.06 & 9.46 & 8.40 & 8.31 \\
\hline 20 & 8.16 & 10.66 & 9.56 & 9.46 \\
\hline 30 & 8.90 & 11.63 & 10.23 & 10.25 \\
\hline \multirow[t]{2}{*}{ Mean } & 7.65 & 10.03 & 8.93 & \\
\hline & & $S$ & $\mathrm{Zn}$ & S xZn \\
\hline \multirow[t]{2}{*}{ 20DAS } & $\mathrm{SE}(\mathrm{M}) \pm$ & 0.08 & 0.07 & 0.15 \\
\hline & $\mathrm{CD}(\mathrm{p}=0.05)$ & 0.26 & 0.22 & NS \\
\hline \multirow[t]{2}{*}{ 40DAS } & $\mathrm{SE}(\mathrm{M}) \pm$ & 0.10 & 0.09 & 0.18 \\
\hline & $\mathrm{CD}(\mathrm{p}=0.05)$ & 0.31 & 0.27 & NS \\
\hline \multirow[t]{2}{*}{ 60DAS } & $\mathrm{SE}(\mathrm{M}) \pm$ & 0.08 & 0.07 & 0.15 \\
\hline & $\mathrm{CD}(\mathrm{p}=0.05)$ & 0.26 & 0.22 & NS \\
\hline
\end{tabular}


Table.5 Test weight of 1000-grains (g) of green gram as influenced by sulphur and Zinc levels

\begin{tabular}{|l|c|c|c|c|}
\hline \multirow{2}{*}{ Level of S(kg/ha) } & \multicolumn{3}{|c|}{ Levels of Zn (kg/ha) } & Mean \\
\cline { 2 - 5 } & 0 & 10 & 15 & 11.81 \\
\hline $\mathbf{0}$ & 9.43 & 13.56 & 12.43 & 13.76 \\
\hline $\mathbf{1 0}$ & 10.46 & 16.26 & 14.56 & 16.00 \\
\hline $\mathbf{2 0}$ & 11.73 & 18.63 & 17.63 & 17.08 \\
\hline $\mathbf{3 0}$ & 14.63 & 19.46 & 17.16 & \\
\hline Mean & 11.56 & 16.98 & 15.45 & \\
\hline $\mathbf{S E}(\mathbf{M}) \pm$ & $\mathrm{S}$ & $\mathrm{Zn}$ & $\mathrm{SxZn}$ & \\
\hline $\mathbf{C D}(\mathbf{p = 0 . 0 5 )}$ & 0.08 & 0.07 & 0.14 & \\
\hline
\end{tabular}

Table.6 Grain yield (q/ha) from of green gram as influenced by sulphur and Zinc levels

\begin{tabular}{|c|c|c|c|c|}
\hline \multirow{2}{*}{ Level of S(kg/ha) } & \multicolumn{3}{|c|}{ Levels of Zn (kg/ha) } & \multirow{2}{*}{ Mean } \\
\cline { 2 - 4 } & 0 & 10 & 15 & \\
\hline $\mathbf{0}$ & 6.90 & 9.43 & 8.36 & 8.23 \\
\hline $\mathbf{1 0}$ & 7.33 & 9.83 & 9.06 & 8.74 \\
\hline $\mathbf{2 0}$ & 8.26 & 10.66 & 9.43 & 9.45 \\
\hline Mean & 9.16 & 12.63 & 11.10 & 10.96 \\
\hline & 7.91 & 10.64 & 9.49 & \\
\hline $\mathbf{S E}(\mathbf{M}) \pm$ & 0.07 & 0.06 & $\mathbf{S x Z n}$ & \\
\hline $\mathbf{C D}(\mathbf{p}=\mathbf{0 . 0 5})$ & 0.21 & 0.18 & 0.12 & \\
\hline
\end{tabular}

Table.7 Straw yield (q/ha) from of green gram as influenced by sulphur and Zinc levels

\begin{tabular}{|c|c|c|c|c|}
\hline \multirow{2}{*}{$\begin{array}{c}\text { Level of } \\
\mathbf{S}(\mathbf{k g} / \mathbf{h a})\end{array}$} & 0 & 10 & \multirow{3}{*}{ Mean } \\
\hline $\mathbf{0}$ & 7.80 & 10.56 & 9.40 & \\
\hline $\mathbf{1 0}$ & 8.56 & 11.53 & 10.43 & 10.17 \\
\hline $\mathbf{2 0}$ & 9.43 & 12.63 & 11.10 & 11.05 \\
\hline $\mathbf{3 0}$ & 10.43 & 12.63 & 11.50 & 11.52 \\
\hline Mean & 9.05 & 11.84 & 10.60 & \\
\hline & $\mathbf{S}$ & $\mathbf{Z n}$ & $\mathbf{S x Z n}$ & \\
\hline $\mathbf{S E}(\mathbf{M}) \pm$ & 0.07 & 0.06 & 0.12 & \\
\hline $\mathbf{C D}(\mathbf{p}=\mathbf{0 . 0 5})$ & 0.22 & 0.19 & 0.38 & \\
\hline
\end{tabular}

The increasing Zinc level only up to $10 \mathrm{~kg} / \mathrm{ha}$ the grain yield significantly up to $10.64 \mathrm{q} / \mathrm{ha}$, as compared to no Zinc (7.91 q/ha).Although the treatment interactions were found to be significant, the best treatment combination appeared to be $\mathrm{S}_{30} \mathrm{Zn}_{10}$ producing $12.63 \mathrm{q} / \mathrm{ha}$ grain. This was followed by $\mathrm{S}_{30} \mathrm{Zn}_{10}$ interactions producing equal grain $(12.63 \mathrm{q} / \mathrm{ha})$ on the other hand the lowest yield only $6.90 \mathrm{q} / \mathrm{ha}$ ware recorded in case of absolute control $\left(\mathrm{S}_{0} \mathrm{Zn}_{0}\right)$. 
The sulphur level only up to $30 \mathrm{~kg} / \mathrm{ha}$ enhanced the straw yield significantly $(11.52$ $\mathrm{q} / \mathrm{ha}$ ) as against no sulphur application (9.25 $\mathrm{q} / \mathrm{ha}$ ). As regards with the Zinc levels, the significantly increasing trend in straw yield was observed up to $10 \mathrm{~kg} \mathrm{Zn} / \mathrm{ha}$. Thus the maximum straw yield was $11.84 \mathrm{q} / \mathrm{ha}$ as against no Zinc application (9.05q/ha).

The treatment interactions proved much more beneficial in augmenting this productivity parameter. The highest straw yield up to $12.63 \mathrm{q} / \mathrm{ha}$ was obtained from $\mathrm{S}_{30} \mathrm{Zn}_{10}$ interaction, which was significantly superior to all the remaining interactions except $\mathrm{S}_{20} \mathrm{Zn}_{10}(12.63 \mathrm{q} / \mathrm{ha})$. Thus, $\mathrm{S}_{20} \mathrm{Zn}_{10}$ proved the second best interaction. On the other hand, the significantly lowest yields $(7.80 \mathrm{q} / \mathrm{ha})$ were recorded in case of control $\left(\mathrm{S}_{0} \mathrm{Zn}_{0}\right)$.

In conclusion the findings elude that application of $30 \mathrm{~kg} \mathrm{~S}$ with $60 \mathrm{~kg}$ P/ha proved the most optimum and the beneficial fertility management for the PDM-139 Variety Green gram for the Bundelkhand/ Chitrakoot region of Madhya Pradesh. This fertility management $\left(\mathrm{S}_{30} \mathrm{Zn}_{10}\right)$. Resulted in maximum seed productivity up to $12.63 \mathrm{q} / \mathrm{ha}$ and straw yield up to $12.63 \mathrm{q} / \mathrm{ha}$.

\section{References}

Khourgami, A. and Fard, S. R. (2012). The effect of Zinc (Zn) spraying and plant density on yield and yield components of green gram. Annals of Biological Research, 3: 4172-4178.

Manivasagaperumal, R. Vijayarengan, P. Balamurugan, S. and Thiyagarajan, G. (2012.) Effect of zinc on growth, dry matter yield and nutrient content of Vigna radiata (L.) Wilczek. International Journal of Recent Scientific Research, 3 (8): 687 -692.

Patel, R. D. Patel, D. D. Chaudhari, M. P. Surve, V. Patel, K. G. And Tandel, B. B. (2013). Response of different cultivars of greengram [Vigna radiata (L.) Wilczek] to integrated nutrient management under south Gujarat condition. An International e-Journal , Vol. 2, Issue 2 132-142

Ram, Surendra and Katiyar, T. P. S (2013). effect of sulphur and zinc on the seed yield and protein content of summer mungbean under arid climate. International Journal of Science \& Nature, 4 (3): 563

Tripathi, H.C., Singh, R.S. and Mishra, U.K. (1997). Effect of $S$ and Zn nutrition on yield and quality of chick pea (Cicer arientinum L). Journal of the Indian society of Soil Science 45: 123-126.

Upadhyay, A. K. (2013) Effect of sulphur and zinc nutrition on yield, uptake of nutrients and quality of lentil in alluvial soil. Annals of Plant and Soil Research 15(2): 160-163.

\section{How to cite this article:}

Opendra Kumar Singh, T. S. Mishra, H. M. Singh and Shubham Dwivedi. 2020. Study on Interaction Effect of Sulphur and Zinc on Different Parameters of Greengram under Rainfed Condition. Int.J.Curr.Microbiol.App.Sci. 9(08): 2260-2268.

doi: https://doi.org/10.20546/ijcmas.2020.908.259 